\title{
Nursing students' perception of training on human sexuality
}

A formação relacionada com a sexualidade humana na perceçáo de estudantes de enfermagem

La formación relacionada con la sexualidad humana en la percepción de los estudiantes de enfermería

Maria das Neves Figueiroa*; Maria Lúcia Neto de Menezes**; Estela Maria Leite Meirelles Monteiro***;

Ângela Roberta Lessa de Andrade****; Débora Priscila Ferreira Fraga****; Monique Vieira de Oliveira******

\section{Abstract}

Background: Sexuality is a dimension in the life of all human beings. It is a continuous process that begins before birth and ends with death.

Objective: To understand undergraduate nursing students' perception of the concept of sexuality and the importance of including the study of sexuality in professional nursing higher education.

Methodology: Descriptive, exploratory study, using qualitative methodology. Data were collected through interviews and analyzed using content analysis techniques.

Results: Participants associated sexuality with a biological need that goes beyond the sexual act and that is influenced by psychological and cultural factors. They highlighted the importance of the topic and reported that it was only superficially addressed during their undergraduate degree.

Conclusion: Sexuality is a key topic in professional nursing training and needs to be more and better explored in undergraduate degrees, namely to expand and optimize these health professionals' performance in situations that address sexuality as a life dimension characterized by unique experiences.

Keywords: education, nursing; sexuality; students, nursing

\section{Resumo}

Enquadramento: A sexualidade é um componente inerente à vida de todos os seres humanos. Desenvolve-se num processo contínuo, que se inicia antes do nascimento e só se encerra com a morte.

Objetivos: Compreender a perceçáo dos universitários do curso de enfermagem sobre o conceito de sexualidade e a importância do estudo da temática da sexualidade na formação profissional.

Metodologia: Estudo descritivo, exploratório, utilizando metodologia qualitativa. A colheita de dados realizou-se a partir de entrevistas e análise de conteúdo.

Resultados: Os entrevistados relacionaram a sexualidade com uma necessidade biológica que vai além do ato sexual e é influenciada por fatores psicológicos e culturais. Relataram a importância da temática, destacando que o tema foi visto durante a graduação de forma superficial.

Conclusáo: A sexualidade constitui-se como temática fundamental na formaçáo do profissional enfermeiro e precisa de ser mais e melhor explorada nos cursos de graduaçáo, inclusive para ampliar e otimizar a atuaçáo destes profissionais de saúde em espaços que contemplem a abordagem da sexualidade como uma dimensão da vida, onde acontecem importantes experiências singulares.

Palavras-chave: educação em enfermagem; sexualidade; estudantes de enfermagem

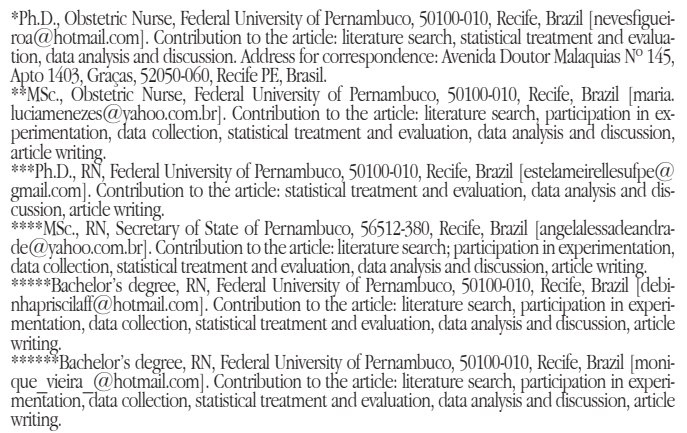
writing

\section{Resumen}

Marco contextual: La sexualidad es un componente inherente a la vida de todos los seres humanos. Se desarrolla en un proceso continuo, que comienza antes del nacimiento y termina con la muerte.

Objetivos: Comprender la percepción de los universitarios de la licenciatura de enfermería sobre el concepto de sexualidad y la importancia del estudio de la temática de la sexualidad en la formación profesional.

Metodología: Estudio descriptivo, exploratorio, en el que se utiliza la metodología cualitativa. La recogida de datos se realizó a partir de entrevistas y del análisis de contenido.

Resultados: Los entrevistados relacionaron la sexualidad con una necesidad biológica más allá del acto sexual y la cual se ve influenciada por factores psicológicos y culturales. Asimismo, señalaron la importancia de la temática y destacaron que, durante el grado, el tema se abordó de forma superficial.

Conclusión: La sexualidad constituye una temática fundamental en la formación del profesional enfermero y necesita que se explote más y mejor en los grados, incluso para ampliar y optimizar la actuación de estos profesionales de la salud en espacios que contemplen el enfoque de la sexualidad como una dimensión de la vida, donde ocurren importantes experiencias singulares.

Palabras clave: educación en enfermería; sexualidad; estudiantes de enfermería 


\section{Introduction}

The term 'sexuality' emerged in the $19^{\text {th }}$ century as more than a mere change in vocabulary, because from that moment on, the meaning of this word became associated with other phenomena, such as the development of different fields of knowledge; the establishment of a set of rules and norms supported by religious, legal, education, and medical institutions; the changes in the way in which individuals value and assign meaning to behaviors, desires, pleasures, feelings, sensations, and dreams (Foucalt, 2015).

However, human sexuality continued to be an understudied topic until the 1960s, when it started to be recognized as a relevant topic. Today it has become an important object of study in Brazilian scientific production (Toneli, 2012). It should be noted that the study of sexuality is complex and subjective and requires a detailed and holistic view to be properly understood. It is an ongoing process that begins at conception and continues throughout life, and that is influenced by multiple factors (Miranda, Santos, \& Oliveira, 2015).

Sexuality is also the most intimate aspect of who we are, and one of the characteristics that identify us as human beings. It is a discipline of the body and takes part in the process of population regulation. It is also a matter of state and a topic of public interest, to the extent that the population's sexual behavior also relates to public health, birth rate, vitality of the offspring and the species, which, in turn, is associated with the production of wealth, the ability to work, settlement patterns, and the power of a society (Pereira \& Monteiro, 2015). However, the wide and unrestricted discussion around the topic of sexuality has been hampered over time due to several reasons, resulting in misconceptions, erroneous subjectivities, beliefs, myths, and taboos, and even leading to unacceptable discrimination in society (Moizés \& Bueno, 2010).

A biopsychosocial care model was recently developed to provide a comprehensive perspective on the human being and the illness process. This paradigm advocates that healthcare professionals' training should go beyond the learning of technical skills and evolve towards the development of relational skills, thus allowing the creation of an appropriate bond and effective communication between professionals and patients (Junqueira, Vieira, Giami, \& Santos, 2013).

The literature review conducted on this topic revealed only a few national and international studies on the introduction of the study of sexuality and its concepts and knowledge into nursing care. The studies on this topic showed that nurses have difficulties in discussing topics related to human sexuality or introduce care interventions concerning the sexual dimension into care prescriptions. In addition, recent studies conducted in this area of knowledge (Rezende \& Sobral, 2016; Sehnem, Ressel, Junges, Silva, \& Barreto, 2013) do not allow assessing if the problems found in the study and faculty training on human sexuality are difficulties that exist in specific institutions or if they extend to other institutions, thus being a problem in different Brazilian regions.

This study is relevant to the extent that it reflects on the integration of sexuality and its concepts into nursing education/training, thus allowing the identification of students' perception of the importance of the topic in an integral and humanized care delivery. Therefore, the study was developed with the purpose of understanding undergraduate nursing students' perceptions of the concept of sexuality and the importance of the study of sexuality in nursing higher education.

\section{Background}

Sexuality is the desire for contact, warmth, affection or love. It includes kissing, displays of affection, and production of pleasure. It is a central and important dimension of the human being, which covers not only the sexual act itself, but also aspects related to identity, sexual orientation, reproduction, values, behaviors, and is influenced by biological, social, psychological, religious, and political factors (Galati, Alves, Delmashio, \& Horta, 2014). The topic is universal and, at the same time, unique for each individual, since everyone has their own history, practices, attitudes, and symbolism (Moizés \& Bueno, 2010).

Sexuality is also seen as a human need, at the 
psychobiological and psychosocial levels. It is a dimension in the life of all human beings. It is a continuous process that begins before birth and ends with death. Sexuality is structured on each individual's biopsychosocial aspects, covering the biological potential, emotions, feelings, beliefs, and conceptions that the individual develops, expands, and modifies throughout the socialization process (Galati et al., 2014).

However, sexuality has been the topic of a veiled discussion throughout the years, which has resulted in misconceptions, sometimes related to erroneous subjectivities that have led to popular rumors and beliefs, and promoted sexual taboos based on conceptions that generate discrimination within the society (Moizés \& Bueno, 2010).

A biopsychosocial care model was recently developed to provide a comprehensive perspective on the human being and the illness process. This paradigm advocates that healthcare professionals' training should go beyond the learning of technical skills and evolve towards the development of relational skills, thus allowing the creation of an appropriate bond and effective communication between professionals and patients (Junqueira et al., 2013).

In nursing, sexuality has been associated with taboos and prejudices which emerge during academic training and professional practice. It is at the moment of care delivery, from the interaction of the bodies of those who deliver care and those who receive it, that sexuality gains space to emerge. However, when veiled, it may be a mechanism that generates anxieties, uncertainties, and mutual constraints (Sehnem, Ressel, Junges et al., 2013).

The training process of Brazilian nurses has changed as a result of the national curriculum guidelines elaborated by the Ministry of Education to define the competencies to be developed during nurses' training process. Nurses have the responsibility to provide education and guidance about multiple topics, namely human sexuality (Conselho Nacional de Educação, Câmara de Educação Superior, 2001).

On the other hand, a study on faculty training on sexuality revealed that teachers still feel unprepared and unable to deal with patients' sexuality, which is explained by lack of information and curriculum contents on patients' sexuality during their initial training in higher education.
Therefore, it is important to include this topic in the curriculum of undergraduate nursing degrees. In clinical practice, nurses will be required to evaluate human beings from all perspectives (biological, psychological, and social); thus, they should have a comprehensive understanding about sexuality since it is intrinsically related to each individual's life (Rezende \& Sobral, 2016). However, health professionals' lack of knowledge about human sexuality leads to a centralization of the professional practice, by restricting it to the biological aspects of sexuality. Consequently, instead of acting as facilitators, most professionals disregard the need to intervene. These professionals often act as (iatrogenic) destructive agents due to prejudice, ignorance, and the need to impose values (Nogueira, Rodrigues, Labegalini, Lopes \& Baldissera, 2017). The integration of the sexuality topic into the context of nursing care should include the various aspects of the complexity that influences our lives. It should be understood in its various dimensions, namely the social and cultural dimensions, which are essential to understanding the multiple factors that influence and determine the expression of sexuality as a human and multidimensional action (Sehnem, Pedro, Budó, Silva, \& Ressel, 2014).

As a humanistic science, nursing is simultaneously associated with the provision of care to ill people and the promotion of health. For this reason, nursing professionals need to be not only technically well prepared but also willing and able to deal with the various aspects of a human being. Given the various facets of nursing care, it is essential to define communication and its application in the process of caring for patients' sexuality (Garcia \& Lisboa, 2012).

The discussion of sexuality during academic training enables the possibility of deconstructing and reconstructing concepts and values that individuals acquire throughout their lives, namely the silence around the topic, the refusal of information, the persistence of ignorance and constant prohibitions. These aspects can be reflected in the professional life, the asexualization of care, the impersonality of relationships, the absence of dialog, the contained emotions and feelings to hide the embarrassment of dealing with the sexual body of the other, among other issues that may emerge during care delivery (Sehnem, Ressel, Pedro, Budó, \& Silva, 2013). 


\section{Research question}

Considering that the discussion of human sexuality during academic training enables the possibility of deconstructing and reconstructing concepts and values that individuals acquire throughout their lives and that the knowledge on the topic contributes to achieving a professional practice that values human beings in their individual aspects, the study was developed based on the following guiding question: What is nursing students' opinion about the concept and importance of academic training on the topic of sexuality?

\section{Methodology}

This was a qualitative and descriptive field study. The methodological procedures used for the classification of the research had an exploratory and descriptive purpose, but the problem was qualitatively addressed. The population was composed of students enrolled in the $5^{\text {th }}$ year (corresponding to the $9^{\text {th }}$ and $10^{\text {th }}$ semester) of the undergraduate nursing degree of the Nossa Senhora das Graças Nursing School of the University of Pernambuco, Recife, Brazil. This academic period was chosen because students integrate the practical activities of this program. Participants were randomly selected based on the following single criterion: nursing student interns at healthcare units who performed nursing care activities.

The sample was determined by saturation of collected data, in a total of seven interviewees: six women and one man, identified as I01 to I07. Participants were informed about the nature and purpose of the study and ensured ethical confidentiality. Data were collected through face-to-face, in-depth interviews carried out by the researchers themselves between August and September 2016.

The following guiding questions were addressed: What do you understand by human sexuality? Do you think that the topic of sexuality should be addressed in the undergraduate curriculum? Why? Did you attend any specific course unit on sexuality during your program? In practical classes, did you feel the need to have some knowledge about sexuality? At what moment?

The interviews lasted on average 15 minutes and were audio recorded upon the participants' authorization. The material obtained through data collection was analyzed after it was transcribed and exhaustively read. Content analysis followed categorical content analysis techniques (Cavalcante, Calixto, \& Pinheiros, 2014).

To facilitate the organization and application of the content analysis technique, a software (Alves, 2014) was used to generate word clouds and give greater prominence to those words that appear more frequently in the text. Based on the interviewees' answers to each question, a word cloud was generated. Based on the word clouds and content analysis, four categories and respective subcategories were created to account for nursing students' perception about the study of sexuality during their undergraduate nursing training.

In order to ensure the reliability and validity criteria, the following steps were taken: guarantee of the accuracy of registration of collected data (recording and transcription); verification of the data obtained from participants; and analysis and development of relations between the data found in the interviews, in order to ensure consistency between the theoretical constructs and the analysis (Ollaik \& Ziller, 2012).

The study complied with the formal requirements of the national and international standards for research involving human beings and was approved by the Ethics Committee of the Hospital Complex HUOC/PROCAPE, Opinion 1.709.879 in September 2016.

\section{Results}

Interviewees were aged 21 to 26 years, lived in Recife, Olinda, and Paulista, and had a family income between one and five minimum wages (which at the time of data collection corresponded to R $\$ 880,00)$. With regard to gender, two interviewees were men and five were women. In relation to religion, four reported being Catholic, one Spiritist, one Protestant, and one Christian. As to their previous schools, most of them had studied in private schools and two reported having studied in public schools.

The exhaustive reading of the interviews' contents lead to the creation of the following categories: Category 1 - Sexuality as a complex 
and multidimensional concept; Category 2 Sexuality as part of integral care; Category 3 - Inadequate study of sexuality in the nursing higher education; and Category 4 - Sexuality as applied knowledge.

\section{$1^{\text {st }}$ Question: What do you understand by human sexuality?}

When questioned about their knowledge of human sexuality, the interviewees agreed mainly on two aspects (Figure 1): the biological aspect, evidenced by the sexual act and pleasure, among others; and the psychological aspect, that influences the individual's sexual reference, as shown below:

Sexuality is associated with the mind, with people's needs for sex and being with another person. . . . It relates to well-being and to how we see ourselves ... If I am a woman and the other person is a man, my sexuality is different from his ... There is already a division from the moment we have different genital organs ... Men and women. (I04; August 2017)

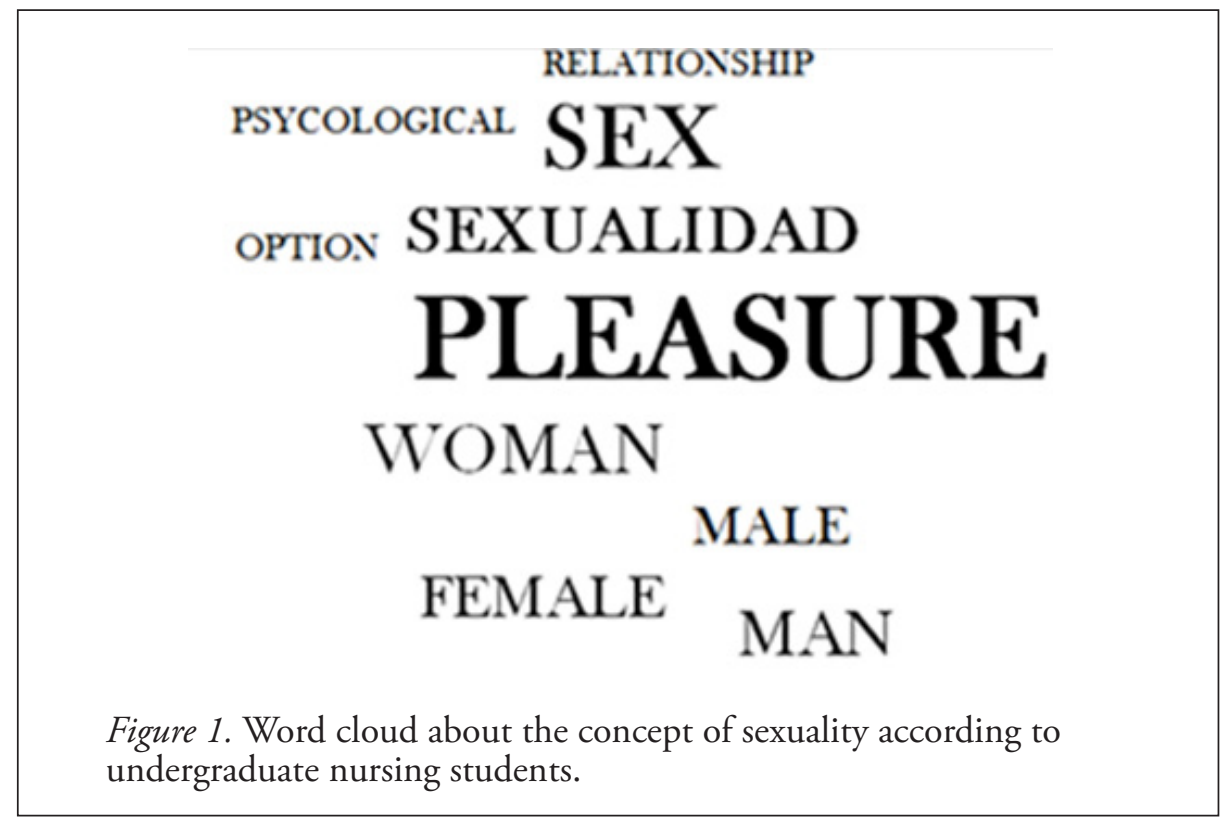

Category 1: Sexuality as a complex and multidimensional concept.

Subcategories: 1 - Sexuality is a necessity; 2 Sexuality is biological domain and is associated with the psychological domain; 3 - Sexuality involves sexual references of psychological and cultural nature; it is a source of pleasure.

$2^{\text {nd }}$ Question: Do you think that the topic of sexuality should be addressed in the undergraduate curriculum? Why?

The interviewees stressed the importance of including the study of sexuality in their training (Figure 2) and justify this by saying that the knowledge about sexuality allows them to care for patients in a holistic way. They consider this learning to be important as a way of re- specting and caring for the patients based on their specificities and needs. This perspective can be observed in the accounts below:

We focus a lot on treating the patient's disease, they may have other problems. ... The more knowledge we have about the subject, the more we will be able to help the patient. . . . We need to respect everyone. (I04; August 2016)

I think so, because we need to know the patient as a whole, isn't it? ... We would need to be psychologically prepared. . . . to learn how to respect these people. . . . It is something that we need to learn about so that we can provide a more comprehensive and high-quality care. (I07; August 2016 ) 


\section{RESPECT \\ LEARN \\ UNDERSTAND \\ RELATIONSHIP \\ KNEDS SEXUALIDAD \\ PLEASURE \\ YES TREAT \\ CARE \\ HELLP}

Figure 2. Word cloud about the importance of the topic of sexuality for nurses' training.

Category 2 - Sexuality as part of integral care. Subcategories: 1 - The study of sexuality helps to know and respect; 2 - The study of sexuality helps to understand the relationship between treating and caring.

$3^{\text {rd }}$ Question: Did you have any specific course on sexuality during your program?

Category 3: Inadequate study of sexuality in the nursing undergraduate degree.

Subcategories: 1 - The contents focused on sexuality are underexplored; 2 - The contents focused on sexuality were insufficient; 3 - The contents focused on sexuality were superficial. When asked about how the topic of sexuality was addressed during their undergraduate nursing degree (i.e., if students had attended a course unit in which sexuality was systematically discussed), most of them answered that they had never attended or did not remember attending one. They also added that the few classroom experiences had been lessons or lectures, which cannot be characterized as a unit specifically focused on the study of sexuality. They reported that the topic was not sufficiently explored or that it was only superficially discussed: "It was nothing significant during the graduation or even in terms of sexuality" (I02; August 2016). "Not that I remember. . . . I think that in women's health.
... I think it was not enough for us to know how to deal with it, especially in clinical practice" (I03; August 2016).

$4^{\text {th }}$ Question: In practical classes, did you feel the need to have some knowledge about sexuality? At what moment?

When asked about the need for knowledge about sexuality during practical classes and internships (Figure 3), most of the interviewees stated that they felt the need for such knowledge and that this lack of knowledge was more evident when students participated in outreach projects and internships at primary healthcare units, during consultations, and even when advising patients. The accounts below highlight this issue:

"You have to know how to explain that to each person and how can you explain something that you haven't learned or experienced?" (I01; August 2016).

If we knew, if we worked on that, I think it could help. . . . In their (patients) daily lives?. . . If we are there to guide, we need to guide. If we had better tools, if there were more. . . . More topics with application into clinical practice, I think that would facilitate more. . . . To help them open up and talk about these issues. (I03; August 2016) 


\section{YES \\ OUTREACH PROJECT IN \\ FAMILY HEALTH PROGRAM \\ AND SEXUALITY \\ TRANSMITTED DISEASES \\ NÃO PREVENTION SEXUALITY CONSULTATIONS}

Figure 3. Word cloud about the applicability of knowledge about sexuality in nurses' performance.

Category 4 - Inadequate study of sexuality as applied knowledge.

Subcategories: 1 - The knowledge about sexuality is important because it helps clinical practice in nursing consultations; 2 - The knowledge about sexuality is important because it helps clinical practice in education activities.

\section{Discussion}

We live in an era of liberation, where many rules, myths, and taboos regarding sexuality have been overcome and/or deconstructed and where various types of knowledge about sexuality are increasingly socialized. Thus, as it was suggested by the interviewees in this study, sexuality has vast and complex conceptual dimensions and can be described in different ways, depending on individual beliefs and (pre)conceptions. The several possibilities of definition converge in a common understanding that sexuality is an intrinsic part of human beings which goes far beyond the sexual act itself, involving the human being as a whole (Toneli, 2012).

However, even knowing that sexuality is part of the life of every human being, it should be noted that the approach to this issue in academic training is quite limited, leaving students - as future professionals - embarrassed and unprepared whenever they have to deal with these situations.

Similarly to what was found in other Brazilian studies (Nogueira et al., 2017; Rezende \& Sobral, 2016), which identified a lack of nursing studies and discussions about sexuality both in academic settings and in professional practice, this study revealed accounts of shame and insecurity when it comes to the topic of sexuality. These expressions are explained by a lack of knowledge about the topic, which, in turn, is associated with the limited discussion of this topic in education experiences.

Knowing that healthcare professionals are responsible for providing care to patients and developing their therapeutic process, they should receive training in this area. With regard to care delivery and health education, many patients have doubts, fears, anxieties, and myths related to sexuality. These results strongly suggest that future professionals are not prepared to investigate, support, and collaborate on a therapeutic basis.

The interviewees stressed the need and importance of addressing the sexual component in all dimensions of care, highlighting that the knowledge about sexuality is essential for the quality of care delivery, regardless of the patient's disease or reason for hospitalization and at all stages of the life cycle. These results are similar to those obtained in another study on the topic (Sehnem, Ressel, Junges et al., 2013), in which students reported the desire to discuss their own 
sexuality and the patients' sexuality, as they believed that it would help them in their practical experiences throughout their degree.

In this context, the World Association for Sexual Health, in its technical documents, reinforces the need to raise educators, health professionals, and students' awareness to the importance of sexual health interventions (Rufino, Medeiros, \& Girão, 2013). Given the scalability of the topic, the integration of this topic into the curriculum of the undergraduate nursing degree must be supported by knowledge sharing, reflection, and change of attitudes to help nursing professionals deliver holistic and comprehensive care.

According to the interviewees' accounts, the superficial way in which the topic of sexuality has been addressed in the undergraduate degree does not correspond to the depth necessary for its application in nursing clinical practice. These results corroborate other studies conducted in Brazil (Sehnem, Ressel, Junges et al., 2013), which revealed that the study of sexuality in undergraduate nursing degrees is limited to a biological and pathological perspective that is casually addressed in nurses' academic training.

Therefore, the lack of theoretical and pedagogical contributions on this topic is a problem for future health professionals, since healthcare needs related to sexual problems or sexual life are frequent in daily clinical practice. Therefore, without proper training, nurses may offer inappropriate sexual guidance, address sexuality from a biological and pathological perspective, or even intervene based on moral precepts, rather than scientific ones, based on a biased view of what is right and/or wrong in relation to sex and gender (Rodrigues \& Wechsler, 2014; Sehnem, Ressel, Junges et al., 2013).

We believe that, regardless of how sexuality was addressed during childhood and adolescence, schools and universities cannot omit or neglect the discussion about the topic. Therefore, undergraduate courses should offer a space and sufficient theoretical-practical support to discuss the topic of sexuality. Teachers should assume their role in this process, acting as facilitators and providing scientific (rather than moral) contributions to ensure that students improve their knowledge and become more confident when dealing with patients' sexuality as professionals who are sensitive to this topic (Reis, Muzzeti, \& Leão, 2014).

Nursing students have recognized the need for knowledge about sexuality during practical classes and internships. According to them, nurses should have sufficient knowledge about sexuality across the different stages of the lifecycle, so that they can explore its complexity and identify the consequences arising from possible diseases.

The sexuality-related themes that emerged from the interviewees' accounts demonstrate the need for nurses to receive training on how to address sexuality-related issues. Students can learn how to deal with these issues from different sources of knowledge, such as training courses, the family, the Internet, textbooks, their own life experiences, the media, and daily clinical practice. Therefore, it is worrying that information is being obtained from scientifically questionable sources that can be associated with specific ethical and moral principles. Sexual guidance requires an evidence-based intellectual or psychological preparation that should be based on ethical and moral neutrality.

In this way, universities should be partners in the development of sexuality-related knowledge, valuing teachers' availability to raise questions about the knowledge on the topic and its association with freedom, pleasure, and the right of access to information.

\section{Conclusion}

This study had limitations because it addresses a specific reality with a subjective approach, which is typical of qualitative studies and makes it impossible to generalize the results. However, its contribution lies in the possibility of encouraging the reflection about undergraduate nursing students' perceptions of the concept of sexuality. Its results may contribute to the evaluation of the syllabus and pedagogical projects of undergraduate nursing degrees and even other health-related degrees concerning the discussion of the sexuality topic throughout the whole degree.

These results and the state-of-the-art on the 
teaching of human sexuality in higher education institutions demonstrate the need for investment in nurses' training. Undergraduate nursing degrees need to incorporate theoretical-practical activities oriented towards the acquisition of clinical skills in the area of sexual health, as well as the assessment of their impact on patient care. The advances in sexual pharmacology have encouraged the management of sexual dysfunctions, and the public shows interest in treating common sexual dysfunctions and symptoms. However, it should be noted that is necessary to broaden the discussion about non-normative sexuality or the social aspects of sexuality. The discussion on the topic of sexuality still tends to focus on organic or pathological aspects. Therefore, other dimensions should also be included in this discussion, namely the notion of rights and concepts that value self-care care and students' training in holistic nursing interventions in the area of sexual health.

\section{References}

Alves, A. D. (2014). Desenvolvimento e aplicaçóes de ferramentas computacionais para o mapeamento de produção cientifica. Retrieved from https://www. capes.gov.br/images/stories/download/pct/mencoeshonrosas/225153.pdf

Cavalcante, R. B., Calixto, P., \& Pinheiros, M. M. (2014). Análise de conteúdo: Considerações gerais, relações com a pergunta de pesquisa, possibilidades e limitações do método. Informaçâoo e Sociedade: Estudos, 24(1), 13-18. Retrieved from http://www.ies.ufpb.br/ojs2/index.php/ies/article/ view/10000/10871

Conselho Nacional de Educação, Câmara de Educação Superior. (2001). Resolução CNE/CES no 3, de 7 de novembro de 2001: Institui diretrizes curriculares nacionais do Curso de Graduação em Enfermagem. Retrieved from http://www.santosjunior.com.br/ Legislacao/resolucaocneces0307112001.pdf

Foucalt, M. (2015). A história da sexualidade: A vontade de saber ( $3^{\mathrm{a}}$ ed., Vol. 1) (M. T. Albuquerque \& J. A. Albuquerque, Trads.). Rio de Janeiro, Brasil: Paz e Terra, 2015.

Galati, M. C., Alves, E. O., Jr., Delmaschio, A. C., \& Horta, A. L. (2014). Sexualidade e qualidade de vida em homens com dificuldades sexuais. Psico-USF, 19(2), 242-252. doi: 10.1590/1413-
82712014019002014

Garcia, O. R., \& Lisboa, L. C. (2012). Consulta de enfermagem em sexualidade: Um instrumento para assistência de enfermagem à saúde da mulher, em nível de atenção primária. Texto e Contexto em Enfermagem, 21(3), 708-716. doi: 10.1590/S010407072012000300028

Junqueira, L. C., Vieira, E. M., Giami, A., \& Santos. M. A. (2013). Análise da comunicação acerca da sexualidade, estabelecida pelas enfermeiras, com pacientes no contexto assistencial do câncer de mama. Interface - Comunicação, Saúde, Educação, 17(44), 89-101. doi: 10.1590/S141432832013000100008

Miranda, C. S., Santos, V. N., \& Oliveira, G. F. (2015). A sexualidade sob o olhar transdisciplinar: Desafios para a prática docente. In XII Congresso Nacional em Educaçâo, Curitiba, Brasil, 26-29 Outubro 2015 (pp. 12328-12339). Retrieved from http://educere. bruc.com.br/arquivo/pdf2015/19127_9411.pdf

Moizés, J. S., \& Bueno, S. M. (2010). Compreensão sobre sexualidade e sexo nas escolas segundo professores do ensino fundamental. Revista da Escola de Enfermagem da USP, 44(1), 205-212. doi: 10.1590/ S0080-62342010000100029

Nogueira, I. S., Rodrigues, D. M., Labegalini, C. M., Lopes, M. C., \& Baldissera, V. D. (2017). A percepção e formação dos acadêmicos de enfermagem acerca da sexualidade humana. Revista de Pesquisa: Cuidado é Fundamental Online, 9(3), 614-619. doi: 10.9789/2175-5361.2017.v9i3.614-619

Ollaik, L. G., \& Ziller, H. M. (2012). Concepçôes de validade em pesquisas qualitativas. Educação $e$ Pesquisa, 38(1), 229-241. doi: 10.1590/S151797022012005000002

Pereira, Z. M., \& Monteiro, S. (2015). Gênero e sexualidade no ensino de ciências no Brasil: Análise da produção científica. Revista Contexto e Educação, 30(95), 117-146. doi: 10.21527/21791309.2015.95.117-146

Reis, F., Muzzeti, L. R., \& Leão, A. M. (2014). Sexualidade e infância: Contribuiçóes da educação sexual em face da erotização da criança em veículos midiáticos. Revista Contrapontos, 14(3), 634-650. doi: 10.14210/contrapontos.v14n3.p634-650

Rezende, A. V., \& Sobral, O. J. (2016). As temáticas relativas à sexualidade humana na formaçáo superior do profissional de enfermagem. Revista Cientifica FacMais, 5(1), 25-39. Retrieved from http://revistacientifica.facmais.com.br/wp-content/ uploads/2016/06/2-\%20As\%20tem\%c3\%a1ticas $\% 20$ relativas $\% 20 \%$ c3\%a0\%20 sexualidade $\% 20$ 
humana $\% 20$ na $\% 20$ forma $\%$ c3\%a7\%c3\%a3o\%20 superior $\% 20 \mathrm{do} \% 20$ profissional $\% 20 \mathrm{de} \% 20$ Enfermagem.pdf

Rodrigues, C. P., \& Wechsler, A. M. (2014). A sexualidade no ambiente escolar: A visão dos professores de educação infantil. Cadernos de Educação: Ensino e Sociedade, 1(1), 89-104. Retrieved from http:// www.unifafibe.com.br/revistasonline/arquivos/cadernodeeducacao/sumario/31/04042014074026. pdf

Rufino, A. C., Medeiros, A. P., \& Girão, M. J. (2013). O ensino da sexualidade nos cursos médicos: A percepção de estudantes do Piauí. Revista Brasileira de Educação Médica, 37(2), 176-185. Retrieved from http://www.scielo.br/pdf/rbem/v37n2/04.pdf

Sehnem, G. D., Pedro, E. N., Budó, M. L., Silva, F. M., \& Ressel, L. B. (2014). A construção da sexualida- de de estudantes de enfermagem e suas percepçôes acerca da temática. Ciencia y Enfermería, 20(1), 111 121. doi: 10.4067/S0717-95532014000100010

Sehnem, G. D., Ressel, L. B., Pedro, E. N., Budó, M. L., \& Silva, F. M. (2013). A sexualidade no cuidado de enfermagem: Retirando véus. Ciência Cuidado e Saúde, 12(1), 72-79. doi: 10.4025/cienccuidsaude. v12i1.16639

Sehnem, G. D., Ressel, L. B., Junges, C. F., Silva, F. M., \& Barreto, C. N. (2013). Sexualidade na formação acadêmica do enfermeiro. Escola Anna Nery, 17(1), 90-96. doi: 10.1590/S1414-81452013000100013

Toneli, M. J. (2012). Sexualidade, gênero e geraçôes: Continuando o debate. In Gênero e sexualidade: História, condiçöes e lugares. Rio de Janeiro, Brasil: Centro Edelstein de Pesquisas Sociais. 